\title{
Overlap in the distributions between indigenous and non-indigenous decapods in a brackish micro-tidal system
}

\author{
Erin Breen ${ }^{1,2, *}$, Anna Metaxas ${ }^{1}$ \\ ${ }^{1}$ Department of Oceanography, Dalhousie University, 1355 Oxford St., Halifax, Nova Scotia B3H 4J1, Canada \\ ${ }^{2}$ Present address: Ministry of Fisheries, PO Box 12034, Napier 4110, New Zealand
}

\begin{abstract}
In the Bras d'Or Lakes, Nova Scotia, Canada, the vertical distributions and abundances of the non-indigenous Carcinus maenas and the indigenous Cancer irroratus and Dyspanopeus sayi were quantified at 4 sites (to a maximum depth of $3.5 \mathrm{~m}$ in 2005), in 3 seasons (spring, summer and fall), in each of 2 years $(2005,2006)$. All species overlap spatially and temporally at $0.5 \mathrm{~m}$ in all seasons and years, indicating a strong potential for biotic interactions (e.g. habitat use, prey consumption). All species, particularly the juvenile stages, were most abundant at shallow $(\leq 1.5 \mathrm{~m})$ depths and were strongly associated with cobble and cobble-composite substrates. C. maenas and D. sayi abundances were also strongly correlated at shallow depths in Benacadie, Ross Ferry and Kempt Head. In 2006, when winter water temperatures were $\sim 1$ to $4^{\circ} \mathrm{C}$ warmer than in 2005 (at which time winter water temperatures were $<0^{\circ} \mathrm{C}$ and ice coverage was extensive), the abundances of $C$. maenas and $D$. sayi were $\sim 1.5$ - to 10 -fold higher, and pronounced pulses in recruitment were observed. The abundance of C. irroratus was low $\left(<0.125\right.$ ind. $\left.\mathrm{m}^{-2}\right)$ in Benacadie (compared to C. maenas and D. sayi, at 0.5 to 10 ind. $\mathrm{m}^{-2}$ ), where salinity regularly falls below 20, a level which is outside the preference and tolerance of $C$. irroratus. Inter-annual differences in water temperatures may influence the survival and abundance of both indigenous and non-indigenous species, which could, in turn, modify biotic interactions among these species.
\end{abstract}

KEY WORDS: Carcinus maenas · Cancer irroratus • Dyspanopeus sayi · Population dynamics · Temperature $\cdot$ Bras d'Or Lakes

\section{INTRODUCTION}

The introductions of non-indigenous species (NIS) into marine ecosystems are a global concern (e.g. Carlton 1989, Carlton \& Geller 1993, Ruiz et al. 1999). The inevitable time lag between the arrival and discovery of an invasive species at a particular location results in inaccurate information about the species' rate of spread and spatial abundance and distribution (Grosholz \& Ruiz 1995), and a limited ability to predict impacts on the local biological community.

Patterns and distributions of NIS are influenced by variations in environmental characteristics that either prevent or facilitate their establishment and survival.
Abiotic factors (e.g. thermal and osmotic stress, flow, substrate) often determine the distributional limits of a species in an estuarine system (Jensen \& Armstrong 1991, Ford 1996, Hunt \& Behrens Yamada 2003). Biotic interactions (e.g. competition, predation) may play a stronger role in determining the lower vertical distributional limit of species (Lonsdale 1999, Hunt \& Behrens Yamada 2003, deRivera et al. 2005). For example, in Oregon, USA, the indigenous Cancer productus does not exploit the upper estuarine system, where salinity is lower and temperature higher, whereas Carcinus maenas (wide temperature and salinity tolerance) was excluded from the lower estuary due to biotic interactions with $C$. productus (Hunt \& Behrens Yamada 
2003). Biotic interactions, however, did not prevent C. maenas from inhabiting the same area (upper estuarine) as indigenous Cancer magister. Resolving the abiotic and biotic factors that determine the success of a NIS will aid in the prediction of interactions with indigenous populations.

The brackish seas within Europe have all been recognized as being highly susceptible to intense invasions by NIS (e.g. Baltic Sea; Leppäkoski \& Olenin 2000). Their susceptibility to invasion is high as result of: (1) increased shipping and boating traffic depositing non-indigenous euryhaline species via ballast water, (2) enhanced establishment opportunities for NIS across wide salinity gradients, and (3) reduced competitive interactions involving NIS in brackish systems with low species richness (Wolff 1998, Leppäkoski \& Olenin 2000, Paavola et al. 2005). The Bras d'Or Lakes (BDOL) in Nova Scotia, Canada (commonly referred to as Canada's Inland Sea) are much smaller than other marginal seas and the Mediterranean $\left(10^{-2}\right.$ to $10^{-3}$ in surface area; $10^{-2}$ to $10^{-5}$ in water volume; Petrie \& Raymond 2002), but they also exhibit strong seasonal and inter-annual salinity gradients and minimal tidal range (3 to $16 \mathrm{~cm}$ ). However, compared to the European systems, the BDOL have a wider seasonal range of salinities ( $<21$ to 32 ), and winter temperatures $<0^{\circ} \mathrm{C}$ can last longer than 2 to $3 \mathrm{mo}$, often resulting in $100 \%$ ice coverage (Petrie \& Bugden 2002). These factors may influence the establishment and potential range of NIS populations and interactions with the native community.

The non-indigenous European green crab Carcinus maenas appeared in the BDOL in the early 1990s (Audet et al. 2003), and its distribution overlaps spatially with 2 indigenous decapods, the rock crab Cancer irroratus and the mud crab Dyspanopeus (Neopanope) sayi (Tremblay 2002, and authors' pers. obs.). However, the extent of the spatial overlap of these 3 species is not clearly understood as their tolerance of and preference for environmental conditions differ slightly (Table 1). The wide environmental tolerance of $C$. maenas makes this species a potentially significant competitor with indigenous decapods, as well as an excellent candidate for successful invasion and expansion into new regions with wide-ranging environmental conditions. However, survival of C. maenas is low when winter water temperatures remain below $3^{\circ} \mathrm{C}$ for $>2$ to $3 \mathrm{mo}$ (Beal 1998), as in the BDOL. The mud crabs Dyspanopeus (Neopanope) sayi are small, cryptic decapods (maximum carapace width [CW] $<30 \mathrm{~mm}$; Williams 1984) that have a wide salinity tolerance and are considered important predators of wild and cultured infaunal juvenile bivalves (MacKenzie 1977, Elner \& Lavoie 1983). Their populations can reach high abundance (e.g. 7 to 225 crabs $\mathrm{m}^{-2}$; Strieb et al. 1995), in turn resulting in high removal rates of prey despite their small size (Elner \& Lavoie 1983, Strieb et al. 1995). Although D. sayi have been mentioned to occur in the Maritimes (Elner \& Lavoie 1983), there is little published information on its ecology, particularly in the BDOL. The rock crab Cancer irroratus is indigenous to coastal and deep waters along eastern North America from Labrador to South Carolina (Rathbun 1930, Squires 1970). It is the largest species found in the BDOL, reaching maximum carapace widths of 119 and $67 \mathrm{~mm}$ (for males and females, respectively; Williams 1984), and preys on invertebrates such as crabs, mussels and sea urchins (Drummond-Davis et al. 1982). Reduced salinities within the central Bras d'Or Lake (21 to 23; Petrie \& Bugden 2002) may influence rock crab abundance and distribution throughout the BDOL, as adults prefer salinities > 25 (Sastry \& McCarthy 1973).

The BDOL provide a unique system to study the establishment, abundance and distribution of the invasive Carcinus maenas in relation to the indigenous Cancer irroratus and Dyspanopeus sayi, because of the combination of extreme environmental conditions and species' differences in tolerance to temperature and salinity. The distributions of C. maenas and D. sayi should overlap throughout the vertical range of $D$. sayi in the BDOL, because they occur on similar substrates (cobble and alga-covered substrates) and have a wide tolerance to salinity. A distributional overlap could increase interspecific interactions and may play a

Table 1. General habitat tolerances of Carcinus maenas, Cancer irroratus and Dyspanopeus sayi, encompassing all life-history stages. CW: carapace width

\begin{tabular}{|c|c|c|c|c|}
\hline Species & $\begin{array}{l}\text { Depth } \\
\text { (m) }\end{array}$ & $\begin{array}{c}\text { Substrate } \\
\text { preferences }\end{array}$ & $\begin{array}{l}\text { Salinity } \\
\text { tolerance }\end{array}$ & $\begin{array}{c}\text { Temperature } \\
\text { tolerance }\end{array}$ \\
\hline $\begin{array}{r}\text { Carcinus } \\
\text { maenas }\end{array}$ & $\begin{array}{l}0-60^{\mathrm{a}} \\
\text { (commonly } \\
\quad<6 \mathrm{~m})\end{array}$ & $\begin{array}{l}\text { Rocky shores, algal } \\
\text { beds, mussel beds, } \\
\text { eelgrass, pebbles }{ }^{\mathrm{a}}\end{array}$ & $4-54^{\mathrm{b}, \mathrm{c}, \mathrm{d}}$ & $0-33^{b, c, d}$ \\
\hline $\begin{array}{l}\text { Dyspanopeus } \\
\text { sayi }\end{array}$ & $0-46^{\mathrm{e}}$ & $\begin{array}{l}\text { Mud, gravel, } \\
\text { crushed shell }^{\mathrm{f}}\end{array}$ & $12.6-32^{f}$ & $0-33$ \\
\hline $\begin{array}{l}\text { Cancer } \\
\text { irroratus }\end{array}$ & $0-800^{9}$ & $\begin{array}{c}\text { Small crabs } \\
(<100 \mathrm{~mm} \text { CW) generally } \\
\text { found nearshore on } \\
\text { both rocky and open } \\
\text { sandy bottoms }\end{array}$ & $25-35^{\mathrm{h}}$ & $0-25$ \\
\hline \multicolumn{5}{|c|}{ 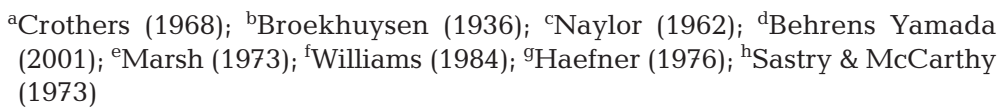 } \\
\hline
\end{tabular}


greater role than abiotic factors in determining the population structure of each species. Conversely, there should be minimal overlap between $C$. irroratus and C. maenas in areas where salinity is low $(<20)$, including the shallow subtidal habitat $(<3 \mathrm{~m}$ depth). In regions of lower salinity and higher temperature, C. maenas may outperform C. irroratus in gaining access to resources. When environmental conditions are favourable to the indigenous $C$. irroratus, stronger biotic resistance to the survival of the non-indigenous C. maenas may be expected (Breen \& Metaxas 2009).

In the present study, we measured the temporal (seasonal and inter-annual) and spatial patterns in the abundance, distribution and size composition of Carcinus maenas, Cancer irroratus and Dyspanopeus sayi in the BDOL. The potential influence of annual temperature variations and substrate composition on crustacean abundance and distribution was also assessed. Our study addresses 3 main questions: (1) Do the species' vertical distributions overlap temporally? If species distributions overlap, there is a strong potential for biotic interactions to influence distribution and population structure. (2) Are there species-specific spatial (horizontal and vertical) and temporal patterns in distribution? Do the same patterns exist in the juvenile stages? Such patterns would indicate species-specific spatial and temporal patterns in habitat use and timing of juvenile recruits to the benthic population. (3) Is there a relationship between species abundance or distribution and substrate type? Identification of patterns in habitat use would enable prediction of loca-

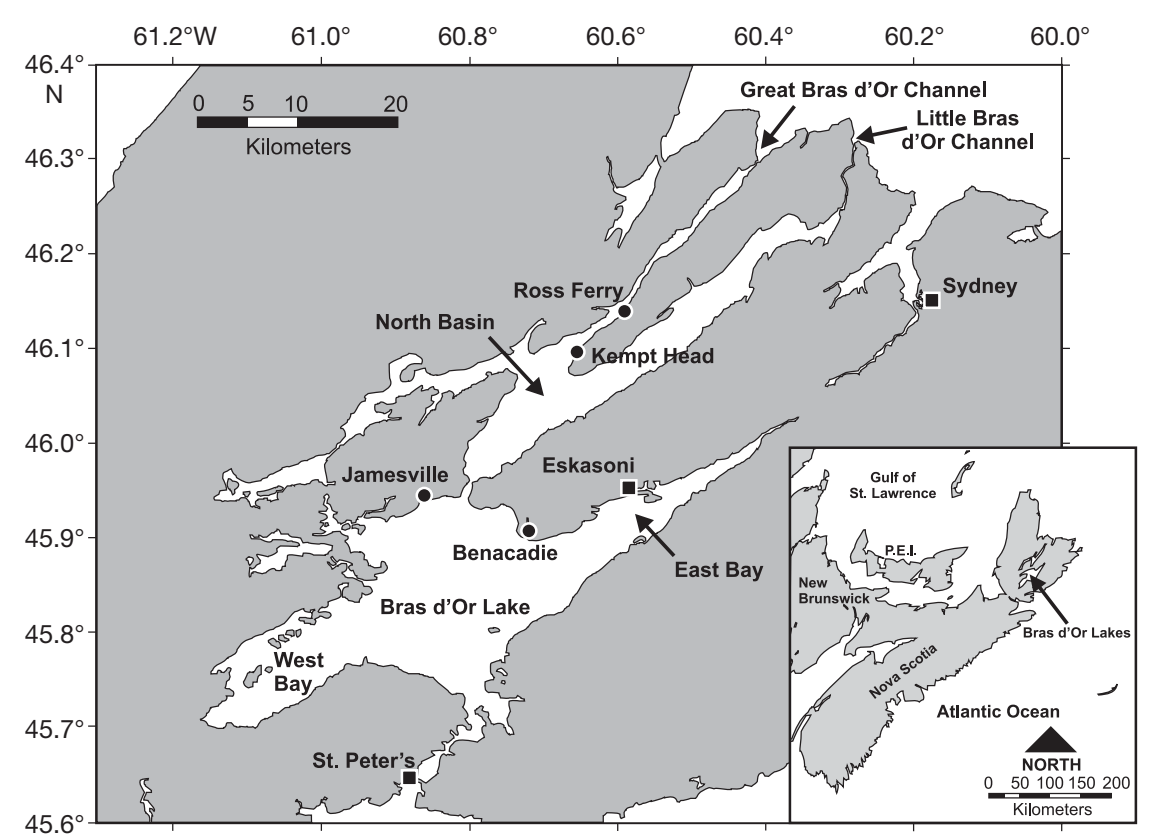

Fig. 1. Chart of the 4 study sites (circles), Jamesville, Benacadie, Ross Ferry and Kempt Head, in the Bras d'Or Lakes, Nova Scotia, Canada. Adapted from Strain \& Yeats (2002) tions for potentially successful establishment of NIS populations. Knowledge of spatio-temporal patterns in abundance, distribution and size structure provides a basis for subsequent management strategies to determine regions susceptible to high predation (bivalve aquaculture sites) and to identify potentially sensitive areas of species overlap, where biological interactions with commercially important species may occur.

\section{MATERIALS AND METHODS}

Study site. The BDOL are located in central Cape Breton, Nova Scotia, Canada, and have 3 connections to the Atlantic Ocean (Fig. 1). Freshwater inflow, the restricted exchange with the Atlantic Ocean and water-atmospheric heat exchange are the primary influences on water circulation, temperature and salinity (Petrie \& Budgen 2002). Near the connections to the Atlantic Ocean (Great Bras d'Or Channel, Little Bras d'Or Channel and St. Peter's Inlet - the lock) salinity generally ranges from 29 to 32, and in the central portions of the lakes, from $<21$ to 23 . However, Petrie \& Budgen (2002) have shown near-surface salinity measurements between 20 and 26 in the Great Bras d'Or Channel, compared to 16-23 in the central Bras d'Or Lake. Point estimates in Benacadie between May 2001 and June 2002 showed a salinity level of $17.4 \pm 6.9$ (mean $\pm \mathrm{SD}, \mathrm{n}=21$ ), with 5 measurements $<15$ and some of these approaching 0 (Cameron \& Metaxas 2005, authors' pers. obs.). Salinity values in the BDOL regularly fluctuate with rainfall, winds and oceanic water exchange. Water temperatures in the winter fall to $\sim 0^{\circ} \mathrm{C}$ throughout the water column, and in summer they often reach $>20^{\circ} \mathrm{C}$ at the surface ( $\leq 5 \mathrm{~m}$ depth).

Field sampling. Decapod populations were sampled at 4 study sites within the BDOL: Jamesville ( $\left.45^{\circ} 56^{\prime} \mathrm{N}, 60^{\circ} 52^{\prime} \mathrm{E}\right)$, Benacadie $\left(45^{\circ} 54^{\prime} \mathrm{N}, 60^{\circ} 53^{\prime} \mathrm{E}\right)$, Ross Ferry $\left(46^{\circ} 8^{\prime} \mathrm{N}, 60^{\circ} 35^{\prime} \mathrm{E}\right)$ and Kempt Head $\left(46^{\circ} 6^{\prime} \mathrm{N}, 60^{\circ} 39^{\prime} \mathrm{E}\right)$ (Fig. 1). The 4 sites were selected because they are known to harbour populations of crabs and to provide coverage of both the Great Bras d'Or Channel and the central Bras d'Or Lake. Most water exchange with the Atlantic Ocean occurs through the Great Bras D'Or Channel with salinities $>26$. In the central Bras d'Or Lake below average salinities $(<26)$ have regularly been recorded. To capture spatial and temporal variability in site characteristics (in terms of tem- 
perature, salinity and flow), the abundances of Carcinus maenas, Cancer irroratus and Dyspanopeus sayi were counted in June (spring), August (summer) and October (autumn) in 2005 and 2006 (a cold year with extensive ice coverage and a warm year with no ice coverage, respectively), using snorkelling or SCUBAdiving depending on depth. The months reflect the seasons when crab activity begins to increase and peaks, and when recruitment is known to occur (spring, summer and fall, respectively) (Cameron \& Metaxas 2005).

At each site, abundance was determined at each of 4 depths where high abundances of juveniles had previously been observed $(0.5,1.5,2.5$ and $3.5 \mathrm{~m}$ when available, i.e. $<45 \mathrm{~m}$ distance from shore) using $0.25 \mathrm{~m}^{2}$ haphazardly placed square quadrats. In each sampling period, all sites were sampled within $36 \mathrm{~h}$. The number of quadrats varied among depths and sites and was based on preliminary sampling done in 2004 (Table 2). Power analysis was used to calculate the minimum number of replicates required to detect a minimum difference of 2 individuals in the abundances among species within a depth, and among depths for a single species. Greater variance in preliminary abundance estimates required more quadrats to be sampled at the shallow depths. Sampling effort was reduced in October 2005 in Benacadie and Kempt Head due to weather conditions and poor visibility that prevented collection of crabs and, in June and October 2006 at all sites ( $>0.5 \mathrm{~m}$ depths), because of logistical constraints. To determine whether there was a significant difference in the estimation of abundance due to diurnal variation in crab behaviour, night sampling was done

Table 2. Number of $0.25 \mathrm{~m}^{2}$ quadrats sampled at each depth (m) at each site (Jamesville, Benacadie, Ross Ferry and Kempt Head) in the Bras d'Or Lakes, Nova Scotia, in 3 seasons in 2005 and 2006. -: not sampled

\begin{tabular}{|c|c|c|c|c|c|c|c|c|}
\hline \multirow{2}{*}{ Site } & \multirow{2}{*}{$\begin{array}{l}\text { Depth } \\
\text { (m) }\end{array}$} & \multicolumn{4}{|c|}{-2005} & \multirow{2}{*}{ Jun } & \multirow{2}{*}{$\begin{array}{l}2006 \\
\text { Aug }\end{array}$} & \multirow[b]{2}{*}{ Oct } \\
\hline & & Jun & Aug & $\begin{array}{c}\text { Aug } \\
\text { (night) }\end{array}$ & Oct & & & \\
\hline \multirow{3}{*}{ Jamesville } & 0.5 & 40 & 40 & - & 40 & 40 & 40 & 20 \\
\hline & 1.5 & 20 & 20 & - & 20 & 0 & 20 & 0 \\
\hline & 2.5 & 20 & 20 & - & 20 & 0 & 20 & 0 \\
\hline \multirow{4}{*}{ Benacadie } & 0.5 & 60 & 60 & 40 & 35 & 60 & 60 & 40 \\
\hline & 1.5 & 20 & 20 & 20 & 20 & 0 & 20 & 0 \\
\hline & 2.5 & 20 & 20 & 20 & 20 & 0 & 20 & 0 \\
\hline & 3.5 & 20 & 20 & 20 & 20 & 0 & 20 & 0 \\
\hline \multirow{4}{*}{ Ross Ferry } & 0.5 & 40 & 40 & 20 & 40 & 40 & 40 & 30 \\
\hline & 1.5 & 20 & 20 & 20 & 20 & 0 & 20 & 0 \\
\hline & 2.5 & 20 & 20 & 20 & 20 & 0 & 20 & 0 \\
\hline & 3.5 & 20 & 20 & 20 & 20 & 0 & 20 & 0 \\
\hline \multirow[t]{3}{*}{ Kempt Head } & 0.5 & 40 & 40 & - & 36 & 40 & 40 & 30 \\
\hline & 1.5 & 20 & 20 & - & 20 & 0 & 20 & 0 \\
\hline & 2.5 & 20 & 20 & - & 0 & 0 & 20 & 0 \\
\hline
\end{tabular}

in the summer of 2005 at Benacadie and Ross Ferry, in addition to daytime sampling. On all dates and at all sites, all crabs (juveniles and adults) within a quadrat were counted, and almost all were collected (some escaped collection), measured (CW) with calipers $( \pm 0.1 \mathrm{~mm})$ and sexed. Quadrat sampling involved the removal of all rocks and the upper sediment layer $(\sim 5 \mathrm{~cm})$ and the collection/counting of all 3 crab species visible on top of the substrate and during the removal of sediment.

In June and August 2005, substrate type was recorded and estimated qualitatively (as percent cover within a $0.25 \mathrm{~m}^{2}$ quadrat). Mean sea surface temperatures (SST) for 2005 and 2006 from the central BDOL (southwest of the Barra Strait) were derived from semimonthly measurements from AVHRR instruments flown on the NOAA series of satellites (NOAA data received and processed by the Remote Sensing Unit at the Bedford Institute of Oceanography).

Statistical analyses. Four-way analyses of the variation (ANOVA) in the abundance of crabs with depth, site, season and year used concurrently were not possible because of lack of orthogonality among all factors. Consequently, we conducted a series of 2-way ANOVAs to make spatial and temporal comparisons in abundance: (1) among depths and seasons, for each species at each site, in 2005 only; (2) among depths and between years, for each species at each site, in August only; (3) among sites and between years, for each species, at $0.5 \mathrm{~m}$ depth pooled across all seasons; and (4) among seasons and between years, for each species at each site, at $0.5 \mathrm{~m}$ depth. Additionally, within Benacadie and Ross Ferry, the abundance of each species was compared across depths and between day and night surveys in 2005, using a 2-way ANOVA. In all analyses, year $(2005,2006)$, site (Jamesville, Benacadie, Ross Ferry, Kempt Head), depth $(0.5,1.5,2.5,3.5 \mathrm{~m})$, season (spring, summer, fall) and time (day, night) were set as fixed factors, because the levels of the factors included in each analysis were selected to represent our sampling criteria (cold vs. warm year; sites across the BDOL that represented locations in the channel and within the central lake and harboured populations of the 3 species; the range of depths where both juvenile and adult crabs were found ${ }_{i}$ the seasons of different stages in population growth; diurnal variation in crab abundance).

For all ANOVAs, heterogeneity of variances was detected using Levene's test (in all cases $\mathrm{p}<0.01$ ). Since we 
could not determine a transformation that would improve heterogeneity, all analyses were done on untransformed data. Since the assumption of heterogeneity was violated in most instances, the $\alpha_{\text {crit }}$ for each test was decreased to 0.025 (Underwood 1981). Post hoc comparisons of treatment means were done using Student-Newman-Keuls (SNK) tests.

Statistical relationship between species abundance and substrate type. We qualitatively estimated the percent composition of substrate type (based on grain texture: silt, mud, sand, pebble, cobble, boulder, or some composite) for each combination of site and depth. Similarity among sites in the average substrate composition was explored with non-metric multidimensional scaling analysis (NMDS) on Euclidean distances. Substrate composition was compared among sites and among depths, with 2 separate analyses of similarities (ANOSIM). The substrate composites most responsible for the observed patterns were identified using analyses of similarity of percentages (SIMPER). All multivariate analyses were done using PRIMER v.6 (Clarke \& Warwick 2001).

Within each site, we examined the relationships between species' abundances and percent of cobble/ cobble composite material on the substrate, pooled across all depths, seasons and years with a Spearman's rank correlation. We also examined the relationships between the abundances (pooled across depths and seasons) of pairs of species (i.e. Cancer irroratus vs. Carcinus maenas; C. irroratus vs. Dyspanopeus sayi; and C. maenas vs. D. sayi) for each year.

\section{RESULTS}

\section{Temperature patterns during the study period}

The average water temperature in the BDOL was from 1 to $4^{\circ} \mathrm{C}$ warmer throughout winter and spring (January to June) in 2006 than in 2005 (Fig. 2). Satellite SSTs (semi-monthly averages) fall, on average, within $0.5^{\circ} \mathrm{C}$ of temperatures measured in situ at each site. Temperatures measured in situ from 15 July to 18 August 2005 in Jamesville and Benacadie (calculated as semi-monthly averages) were within $0.6 \pm 0.4$ and $0.3 \pm 0.04^{\circ} \mathrm{C}$, respectively, of satellite-derived temperatures. Mean differences in shallow water temperatures of up to $4-6^{\circ} \mathrm{C}$ can occur among various locations within the BDOL in a single time period (Petrie \& Budgen 2002, authors' pers. obs.). However, concurrent measurements between our sampling sites in the spring and summer revealed mean differences from 0.5 to $1.2^{\circ} \mathrm{C}( \pm 0.5$ and 1.0 , respectively). The maximum satellite SSTs observed in summer in 2005 and 2006 were 21.8 and $21.4^{\circ} \mathrm{C}$, respectively.

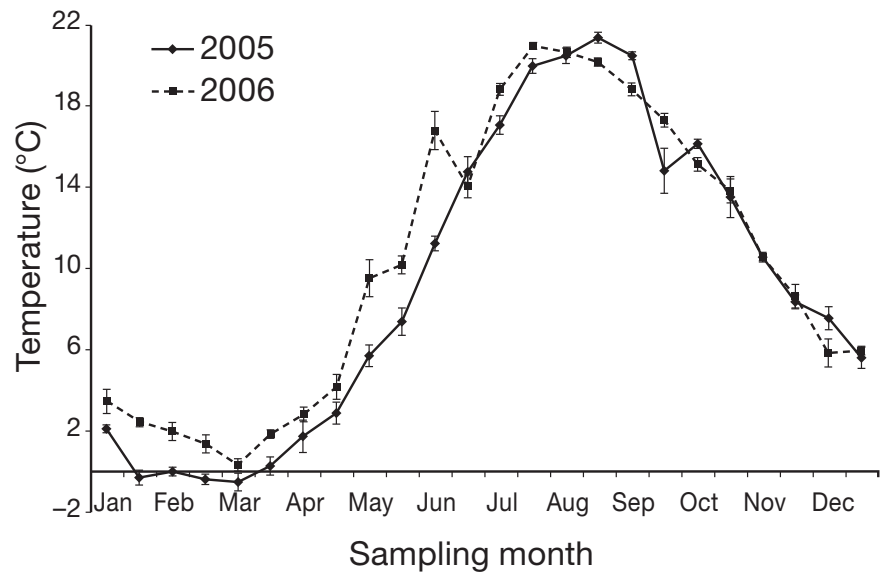

Fig. 2. Semi-monthly sea-surface temperatures (mean $\pm \mathrm{SD}$, $\mathrm{n}=11$ to 40) from the central Bras d'Or Lake, in 2005 and 2006. NOAA data received and processed by the Remote Sensing Unit at the Bedford Institute of Oceanography, Nova Scotia, Canada

In winter 2006 , temperatures $<0^{\circ} \mathrm{C}$ were not sustained, resulting in minimal ice coverage in the BDOL compared to 2005. Ice coverage was absent from 14 to 28 February 2005, but there was a five- to nine-tenths ice coverage (first-year ice: 70 to $120+\mathrm{cm}$ thick) from 24 January to 7 February 2005, and again by 7 March 2005 (Regional Ice Charts, Canadian Ice Service 2008, http://ice-glaces.ec.gc.ca). Ice coverage did not dissipate from the BDOL until approximately 21 March 2005. In 2006, the only ice coverage was five-tenths (first-year ice: 70 to $120 \mathrm{~cm}$ thick) around 23 January. No ice coverage was observed after 30 January 2006, and open water conditions remained for the rest of the winter period. The minimum satellite SSTs observed in winter in 2005 and 2006 were -1.25 and $-1.00^{\circ} \mathrm{C}$, respectively.

\section{Vertical patterns in total abundance}

The distributions of Carcinus maenas, Cancer irroratus and Dyspanopeus sayi overlapped across depths at most sites in both years. We explored temporal variability in the patterns in vertical distribution with 2 analyses: across seasons within a year and between years in August. The greatest abundances occurred at depths of $\leq 1.5 \mathrm{~m}$ at most sites, although there was some seasonal variation in this pattern (Table S1, available at http://www.int-res.com/articles/suppl/b008p001_ app.pdf, Fig. 3). For both C. maenas and D. sayi in 2005, where and when abundance varied with depth, it was greatest at $0.5 \mathrm{~m}$ (Benacadie, in August for both species; Ross Ferry and Kempt Head, all seasons for C. maenas; Ross Ferry, in August and October, and 


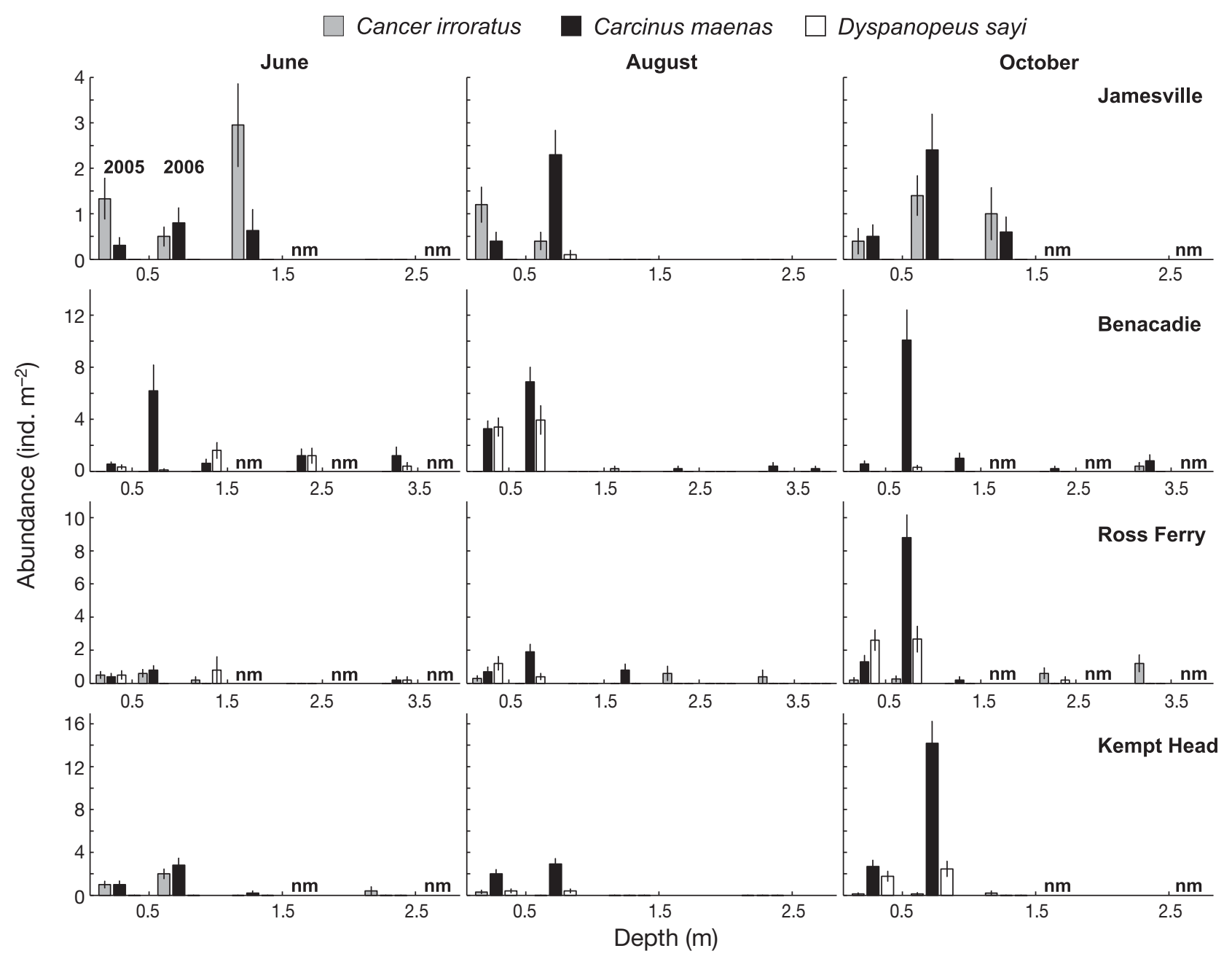

Fig. 3. Cancer irroratus, Carcinus maenas and Dyspanopeus sayi. Abundance (mean \pm SE, n: see Table 2) of species sampled at different depths and seasons, in 2005 and 2006, at Jamesville, Benacadie, Ross Ferry and Kempt Head. nm: not measured

Kempt Head, in October, for D. sayi) (Tables S1 and S2, available at http://www.int-res.com/articles/suppl/ b008p001_app.pdf). There were no D. sayi recorded at Jamesville in 2005 (Fig. 3). The abundance of C. irroratus was greatest at $1.5 \mathrm{~m}$ in June (spring) at Jamesville and at $3.5 \mathrm{~m}$ in October in Benacadie.

Interannual differences in vertical distribution could only be examined in August, but patterns were consistent between years. The abundance of Carcinus maenas was greatest at $0.5 \mathrm{~m}$ at Benacadie, Ross Ferry and Kempt Head in both years and at Jamesville in 2006 (Table S2, Fig. 3). For Dyspanopeus sayi, abundance was also greatest at $0.5 \mathrm{~m}$ at Benacadie and Ross Ferry in both years and at Jamesville in 2006 only. For Cancer irroratus, abundance varied with depth in both years only at Jamesville. In August 2006, C. irroratus was only recorded at $1.5 \mathrm{~m}$ in Benacadie, and was not recorded at either Ross Ferry or Kempt Head.

\section{Vertical patterns in juvenile distribution}

Juveniles of Carcinus maenas, Cancer irroratus and Dyspanopeus sayi also occurred primarily at $0.5 \mathrm{~m}$ at all sites in 2005 and in August 2006 (Table 3), with 2 exceptions: both juvenile C. maenas and $C$. irroratus were found at $1.5 \mathrm{~m}$ in June at Jamesville, and juvenile C. irroratus were recorded at $2.5 \mathrm{~m}$ in October at Ross Ferry,

There was a pronounced pulse of juvenile Carcinus maenas (5.1 to $10 \mathrm{~mm} \mathrm{CW}$ ) at Ross Ferry and of Dyspanopeus sayi (2.1 to $6 \mathrm{~mm} \mathrm{CW}$ ) at Kempt Head, and a smaller increase of larger juvenile C. maenas (10.1 to $15 \mathrm{~mm} \mathrm{CW}$ ) at Benacadie, in October 2006, when abundance was $>8$ - to 10 -fold higher than in October 2005 (Figs. 4 \& 5). In the BDOL, newly settled C. maenas were estimated to have a CW from 1 to $6 \mathrm{~mm}$ (Cameron \& Metaxas 2005). In October 2006, at Ross Ferry and Kempt Head, newly settled C. maenas (1 to 
Table 3. Cancer irroratus, Carcinus maenas and Dyspanopeus sayi. Mean abundance (SE shown in brackets); n: see Table 2) of juveniles sampled at different depths and seasons, in 2005 and 2006, at Jamesville, Benacadie, Ross Ferry and Kempt Head. -: not sampled

\begin{tabular}{|c|c|c|c|c|c|c|c|c|c|}
\hline \multirow[b]{2}{*}{ Month } & \multirow[b]{2}{*}{ Year } & \multirow[b]{2}{*}{ Species } & \multicolumn{3}{|c|}{ Jamesville } & \multicolumn{4}{|c|}{ Benacadie } \\
\hline & & & $0.5 \mathrm{~m}$ & $1.5 \mathrm{~m}$ & $2.5 \mathrm{~m}$ & $0.5 \mathrm{~m}$ & $1.5 \mathrm{~m}$ & $2.5 \mathrm{~m}$ & $3.5 \mathrm{~m}$ \\
\hline \multirow[t]{6}{*}{ June } & \multirow[t]{3}{*}{2005} & Cancer irroratus & $0.92(0.40)$ & $1.89(0.71)$ & 0 & 0 & 0 & 0 & 0 \\
\hline & & Carcinus maenas & $0.31(0.17)$ & $0.21(0.21)$ & 0 & $0.33(0.14)$ & 0 & 0 & 0 \\
\hline & & Dyspanopeus sayi & 0 & 0 & 0 & 0 & 0 & 0 & 0 \\
\hline & \multirow[t]{3}{*}{2006} & Cancer irroratus & $0.40(0.19)$ & - & - & 0 & - & - & - \\
\hline & & Carcinus maenas & $0.80(0.33)$ & - & - & $6.10(1.93)$ & - & - & - \\
\hline & & Dyspanopeus sayi & 0 & - & - & 0 & - & - & - \\
\hline \multirow[t]{6}{*}{ August } & \multirow[t]{3}{*}{2005} & Cancer irroratus & $1.10(0.38)$ & 0 & 0 & 0 & 0 & 0 & 0 \\
\hline & & Carcinus maenas & $0.40(0.19)$ & 0 & 0 & $2.87(0.56)$ & 0 & 0 & 0 \\
\hline & & Dyspanopeus sayi & 0 & 0 & 0 & $0.13(0.09)$ & 0 & 0 & 0 \\
\hline & \multirow[t]{3}{*}{2006} & Cancer irroratus & $0.40(0.19)$ & 0 & - & 0 & 0 & 0 & 0 \\
\hline & & Carcinus maenas & $2.10(0.54)$ & 0 & - & $6.47(1.08)$ & 0 & 0 & $0.20(0.20)$ \\
\hline & & Dyspanopeus sayi & 0 & 0 & - & $0.20(0.11)$ & 0 & 0 & 0 \\
\hline \multirow[t]{6}{*}{ October } & \multirow[t]{3}{*}{2005} & Cancer irroratus & $0.20(0.20)$ & 0 & - & 0 & 0 & 0 & 0 \\
\hline & & Carcinus maenas & $0.40(0.24)$ & 0 & - & $0.57(0.22)$ & 0 & 0 & 0 \\
\hline & & Dyspanopeus sayi & 0 & 0 & - & 0 & 0 & 0 & 0 \\
\hline & \multirow[t]{3}{*}{2006} & Cancer irroratus & $1.00(0.40)$ & - & - & 0 & - & - & - \\
\hline & & Carcinus maenas & $1.00(0.49)$ & - & - & $9.70(2.33)$ & - & - & - \\
\hline & & Dyspanopeus sayi & 0 & - & - & $0.10(0.10)$ & - & - & - \\
\hline \multirow[b]{2}{*}{ Month } & \multirow[b]{2}{*}{ Year } & \multirow[b]{2}{*}{ Species } & \multicolumn{3}{|c|}{ - Ross Ferry - } & & \multicolumn{3}{|c|}{-Kempt Head } \\
\hline & & & $0.5 \mathrm{~m}$ & $1.5 \mathrm{~m}$ & $2.5 \mathrm{~m}$ & $3.5 \mathrm{~m}$ & $0.5 \mathrm{~m}$ & $1.5 \mathrm{~m}$ & $2.5 \mathrm{~m}$ \\
\hline \multirow{6}{*}{ June } & \multirow[t]{3}{*}{2005} & Cancer irroratus & $0.20(0.14)$ & 0 & 0 & 0 & $0.20(0.14)$ & 0 & 0 \\
\hline & & Carcinus maenas & $0.30(0.17)$ & 0 & 0 & 0 & $0.40(0.19)$ & 0 & 0 \\
\hline & & Dyspanopeus sayi & 0 & 0 & 0 & 0 & 0 & 0 & 0 \\
\hline & \multirow[t]{3}{*}{2006} & Cancer irroratus & $0.10(0.10)$ & - & - & - & $0.60(0.23)$ & - & - \\
\hline & & Carcinus maenas & $0.60(0.23)$ & - & - & - & $2.20(0.53)$ & - & - \\
\hline & & Dyspanopeus sayi & 0 & - & - & - & 0 & - & - \\
\hline \multirow{6}{*}{ August } & \multirow[t]{3}{*}{2005} & Cancer irroratus & 0 & 0 & 0 & 0 & $0.20(0.14)$ & 0 & 0 \\
\hline & & Carcinus maenas & $0.70(0.28)$ & 0 & 0 & 0 & $1.70(0.38)$ & 0 & 0 \\
\hline & & Dyspanopeus sayi & $0.20(0.20)$ & 0 & 0 & 0 & 0 & 0 & 0 \\
\hline & 2006 & Cancer irroratus & $0.10(0.10)$ & 0 & 0 & 0 & 0 & 0 & 0 \\
\hline & & Carcinus maenas & $1.70(0.43)$ & 0 & 0 & 0 & $2.60(0.55)$ & 0 & 0 \\
\hline & & Dyspanopeus sayi & 0 & 0 & 0 & 0 & $0.10(0.10)$ & 0 & 0 \\
\hline October & 2005 & Cancer irroratus & 0 & 0 & $0.20(0.20)$ & 0 & 0 & 0 & 0 \\
\hline & & Carcinus maenas & $0.80(0.36)$ & 0 & 0 & 0 & $1.22(0.55)$ & 0 & 0 \\
\hline & & Dyspanopeus sayi & $1.10(0.43)$ & 0 & 0 & 0 & $0.56(0.28)$ & 0 & 0 \\
\hline & 2006 & Cancer irroratus & 0 & - & - & - & $0.13(0.13)$ & - & - \\
\hline & & Carcinus maenas & $7.87(1.33)$ & - & - & - & $13.42(1.98)$ & - & - \\
\hline & & Dyspanopeus sayi & $0.40(0.22)$ & - & - & - & $1.29(0.54)$ & - & - \\
\hline
\end{tabular}

$6 \mathrm{~mm} \mathrm{CW}$ ) were evident and a pulse in the abundance of 5.1 to $10 \mathrm{~mm} \mathrm{CW}$ crabs occurred. Although there was a greater number of 5.1 to $10 \mathrm{~mm} \mathrm{CW} \mathrm{C.} \mathrm{maenas}$ at both sites in 2006 than in 2005, there was no evidence of these smaller crabs earlier in the season (June or August; Fig. 4, authors' unpubl. data) at Ross Ferry, and only a small number ( 10 per $\left.100 \mathrm{~m}^{-2}\right)$ were present at Kempt Head (August; authors' unpubl. data). Most of the crabs at Ross Ferry and Kempt Head in the 5.1 to $10 \mathrm{~mm} \mathrm{CW}$ bin range were $<8 \mathrm{~mm} \mathrm{CW}$, and probably recently moulted settlers rather than overwintering survivors.

Conversely, at Benacadie, a pulse of 5.1 to $10 \mathrm{~mm}$ CW Carcinus maenas was present as early as June 2006, suggesting that these crabs had settled in the previous year, survived the winter, and continued to grow through the summer, resulting in a large abundance of 10.1 to $15 \mathrm{~mm} \mathrm{CW}$ individuals in October 2006. At Jamesville, there was no evidence of a recruitment pulse of C. maenas in October 2006, although a large abundance $\left(\sim 50\right.$ per $\left.100 \mathrm{~m}^{-2}\right)$ of 10.1 to $15 \mathrm{~mm} \mathrm{CW}$ crabs in June 2006 also suggests high survival over the previous winter (authors' unpubl. data).

In October 2006, newly settled Dyspanopeus sayi $(<8$ mm CW) were present at Kempt Head, with pulses in the abundance of crabs with carapace widths from 2.1 to 4 and from 4.1 to $6 \mathrm{~mm}$. At Ross Ferry, there was a consecutive increase in the abundance of both juvenile and small D. sayi $(4.1-6,8.1-10,12.1-14 \mathrm{~mm} \mathrm{CW})$ and a pronounced peak of 14.1 and $16 \mathrm{~mm} \mathrm{CW}$ individuals (Fig. 5). 


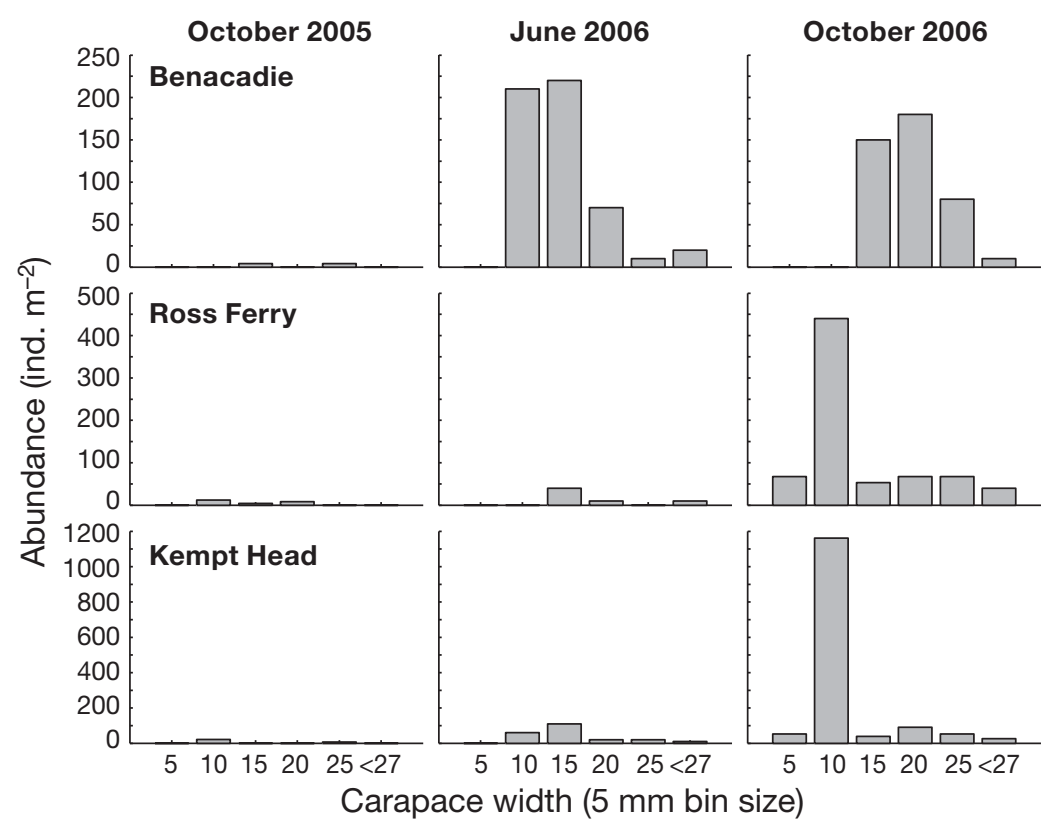

Fig. 4. Carcinus maenas. Size-frequency distributions of juveniles $(\leq 27 \mathrm{~mm}$ carapace width) sampled at Benacadie, Ross Ferry and Kempt Head, in October 2005, June 2006 and October 2006

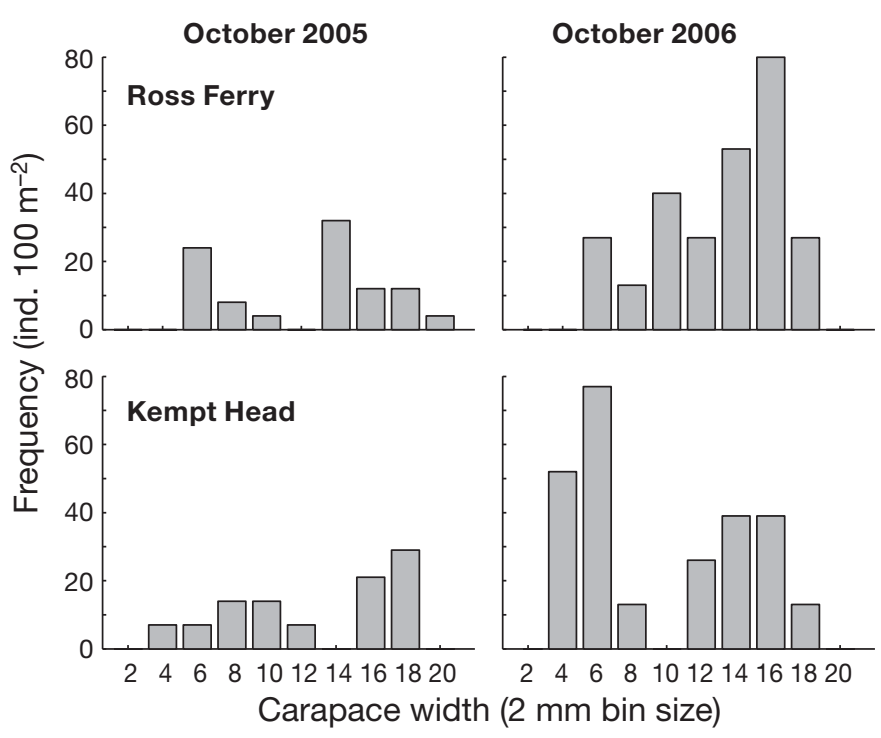

Fig. 5. Dyspanopeus sayi. Size-frequency distributions sampled at Ross Ferry and Kempt Head, in October 2005 and 2006

\section{Horizontal patterns in total abundance}

The abundance of Cancer irroratus and Dyspanopeus sayi varied significantly among sites for both years, whereas the effect of site on Carcinus maenas varied between years (Table S3, available at http://www. int-res.com/articles/suppl/b008p001_app.pdf; Fig. 6). In both years, the abundance of $C$. irroratus was greatest at Jamesville and lowest at Benacadie, whereas that of $D$. sayi was greatest at Benacadie and Ross Ferry. For C. maenas, in 2006, abundance was lowest at Jamesville and highest at Benacadie.

\section{Temporal patterns in total abundance}

Patterns in seasonal variation between years were examined using only data from $0.5 \mathrm{~m}$ depth, and they were not consistent across species (Table S4, available at http://www.intres.com/articles/suppl/b008p001_app. pdf; Fig. 6). For Cancer irroratus, abundance was greatest in June at Jamesville (only in 2005) and Kempt Head (both years), and abundance did not vary between years. Carcinus maenas was more abundant in 2006 than in 2005 at both Jamesville and Benacadie. In both years, abundance was lowest in June at Jamesville and it was greatest in October (2006 only) at both Ross Ferry and Kempt Head. The abundance of Dyspanopeus sayi did not vary between years. It was greater in August than in the other 2 seasons at Benacadie and in October at Ross Ferry and Kempt Head.

To ensure that we were not biasing our daytime observations during a period of reduced crab activity, we compared the abundances of all crab species between surveys done during both the daytime and night in August 2005 at Benacadie and Ross Ferry (Table S5, available at http://www.int-res.com/articles/ suppl/b008p001_app.pdf; Table 4). For all species, abundance did not vary between day and night collections at either site.

\section{Relationship between species abundance and substrate}

Sites grouped according to their substrate composition (Fig. 7), and ANOSIM showed a significant difference in substrate composition between 0.5 and $1.5 \mathrm{~m}$ and between 0.5 and $2.5 \mathrm{~m}$ depths (Table 5). Substrate composition also varied across sites, particularly, between Jamesville and Ross Ferry.

SIMPER analysis indicated that the greatest average dissimilarity was between 0.5 and $2.5 \mathrm{~m}(87.8 \%)$, followed by between 0.5 and $1.5 \mathrm{~m}$ (68.7\%) (Table S6, available at http://www.int-res.com/articles/suppl/ b008p001_app.pdf; Fig. 8). The substrates that primarily contributed to the dissimilarity observed across 


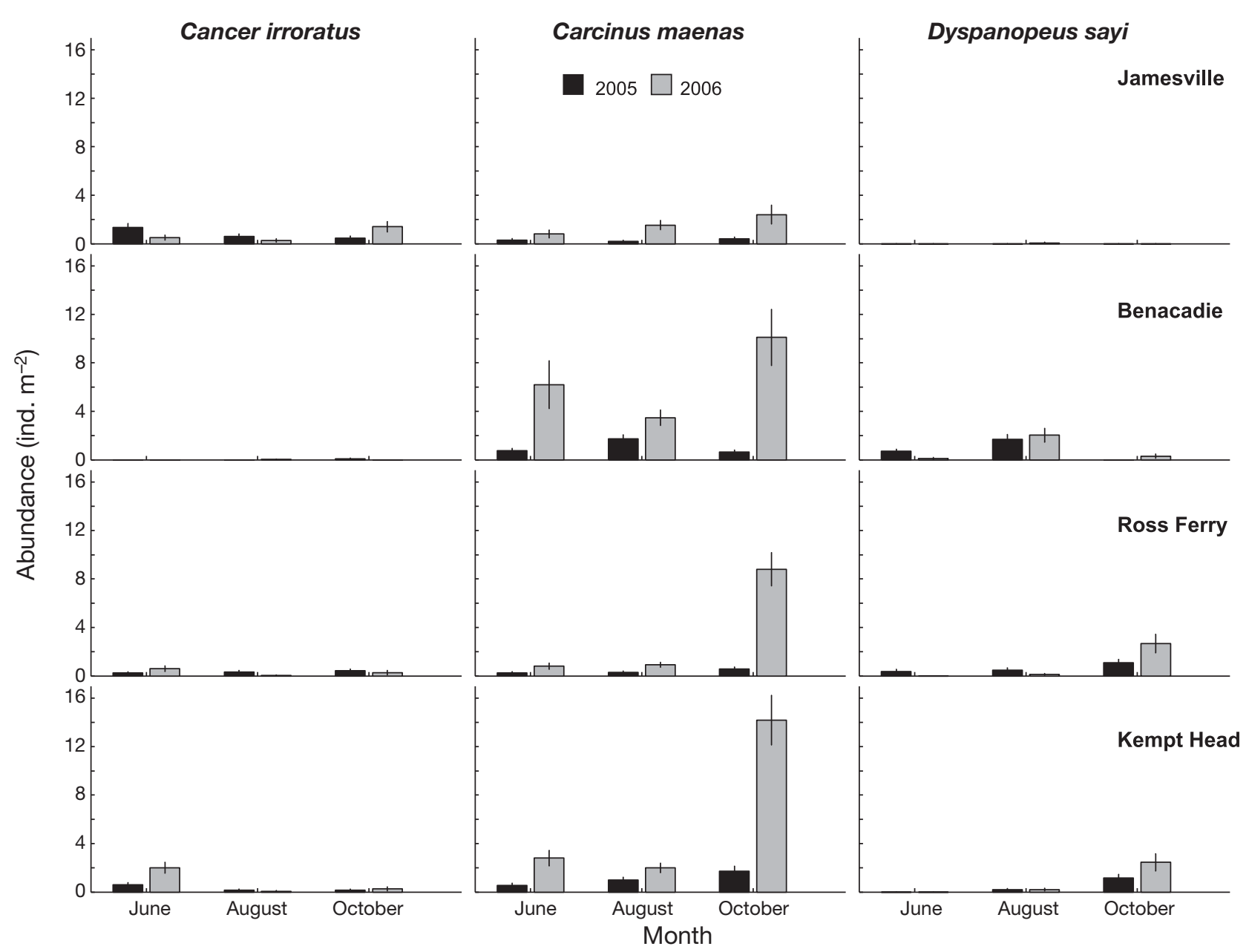

Fig. 6. Cancer irroratus, Carcinus maenas and Dyspanopeus sayi. Abundance (mean \pm SE, n: see Table 2) pooled across depths in 3 different seasons at Jamesville, Benacadie, Ross Ferry and Kempt Head, in 2005 and 2006, in the Bras d'Or Lakes, Nova Scotia, Canada

Table 5. Cancer irroratus, Carcinus maenas and Dyspanopeus sayi. Mean abundance (SE shown in brackets; $\mathrm{n}$ : see Table 2) of populations sampled at 4 different depths, during day and night surveys at Benacadie and Ross Ferry in August 2005

\begin{tabular}{|c|c|c|c|c|c|}
\hline \multirow[b]{2}{*}{ Species } & \multirow{2}{*}{$\begin{array}{l}\text { Depth } \\
\text { (m) }\end{array}$} & \multicolumn{2}{|c|}{- Benacadie } & \multicolumn{2}{|c|}{ Ross Ferry } \\
\hline & & Day & Night & Day & Night \\
\hline \multirow[t]{4}{*}{ Cancer irroratus } & 0.5 & 0 & $0.20(0.20)$ & $0.30(0.17)$ & $0.40(0.28)$ \\
\hline & 1.5 & 0 & $0.20(0.20)$ & 0 & 0 \\
\hline & 2.5 & $0.20(0.20)$ & 0 & 0 & $0.60(0.44)$ \\
\hline & 3.5 & $0.20(0.20)$ & 0 & 0 & $0.40(0.40)$ \\
\hline \multirow[t]{4}{*}{ Carcinus maenas } & 0.5 & $3.27(0.60)$ & $1.70(1.40)$ & $0.70(0.28)$ & $0.60(0.33)$ \\
\hline & 1.5 & 0 & 0 & 0 & $0.20(0.20)$ \\
\hline & 2.5 & 0 & $0.20(0.20)$ & $0.40(0.28)$ & 0 \\
\hline & 3.5 & 0 & $0.40(0.28)$ & 0 & 0 \\
\hline \multirow[t]{4}{*}{ Dyspanopeus sayi } & 0.5 & $3.40(0.71)$ & $2.50(0.99)$ & $1.20(0.41)$ & $0.80(0.37)$ \\
\hline & 1.5 & 0 & $0.20(0.20)$ & 0 & 0 \\
\hline & 2.5 & $0.20(0.20)$ & 0 & 0 & 0 \\
\hline & 3.5 & $0.60(0.33)$ & 0 & 0 & 0 \\
\hline
\end{tabular}

depths were sand $(27.7$ and $29.9 \%$, respectively) and cobble and cobble/ pebble composite (31.6 and $34.0 \%$, respectively). Among sites, average dissimilarity was greatest between Jamesville and Ross Ferry (81.2\%), and, as for across depths, the substrates that primarily contributed to this dissimilarity were sand $(30.6 \%)$ and cobble/silt composite $(17.2 \%$ ) (Table S7, available at http://www.int-res.com/ articles/suppl/b008p001_app.pdf).

There was a significant correlation between the abundance of Carcinus maenas and the amount of cobble/cobble composite substrates at all sites (Jamesville: $\mathrm{r}=0.23$; Benacadie: $\mathrm{r}=0.32$; Ross Ferry: $\mathrm{r}=0.36$; Kempt Head: $\mathrm{r}=0.45 ; \mathrm{p}<$ 0.001 in all cases; Table S8, available at 
(a)

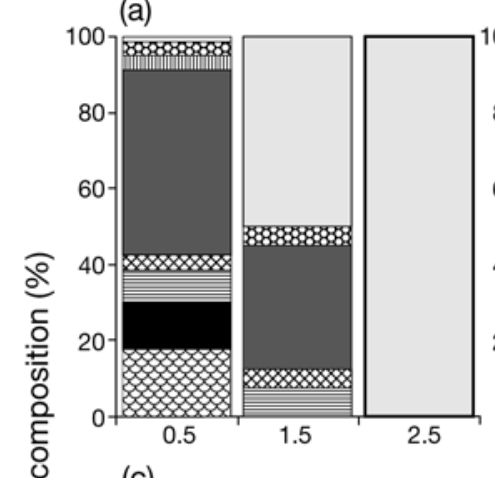

(b)

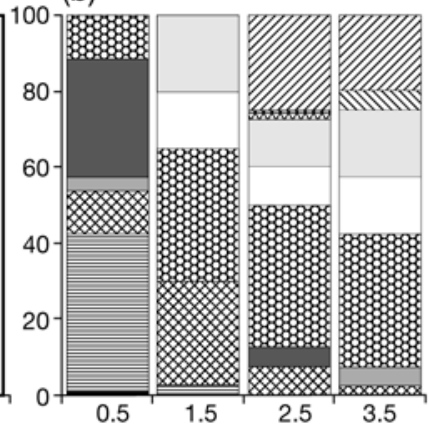

(d)
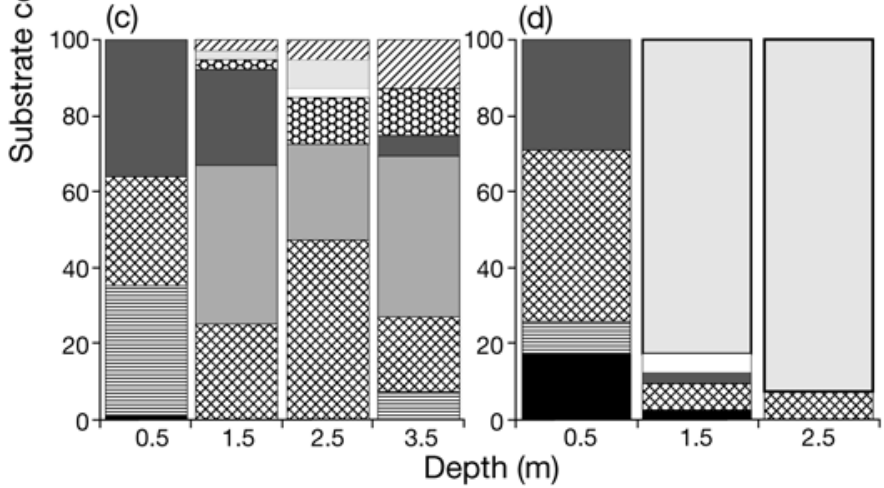

Fig. 7. Percent substrate composition at different depths at: (a) Jamesville, (b) Benacadie, (c) Ross Ferry and (d) Kempt Head in the Bras d'Or Lakes, Nova Scotia, Canada. Substrate components, ordered from smallest to largest size composites - si: silt; m: mud; sm: sand and mud composite; s: sand; sp: sand and pebble composite; p: pebble; pb: pebble and boulder composite; c: cobble; csi: cobble and silt composite; cs: cobble and sand composite; cp: cobble and pebble composite; cps: cobble, pebble and sand composite; cpb: cobble, pebble and boulder composite

Table 5. Summary of the results from analysis of similarity, examining substrate composition between depths and across sites. Bold print: significant at $\mathrm{p}<0.05$

\begin{tabular}{|lcc|}
\hline Test & R-statistic & p-value \\
\hline $\begin{array}{l}\text { Global for depths } \\
\text { Between depths }\end{array}$ & 0.256 & 0.061 \\
$0.5,1.5$ & 0.479 & $\mathbf{0 . 0 2 9}$ \\
$0.5,2.5$ & 0.604 & $\mathbf{0 . 0 2 9}$ \\
$0.5,3.5$ & 1.000 & 0.067 \\
& & \\
Global for sites & 0.393 & $\mathbf{0 . 0 1 2}$ \\
Between sites & 0.500 & 0.057 \\
Jamesville, Benacadie & 0.630 & $\mathbf{0 . 0 2 9}$ \\
Jamesville, Ross Ferry & 0.427 & 0.086 \\
Benacadie, Ross Ferry & & \\
\hline
\end{tabular}

http://www.int-res.com/articles/suppl/b008p001_app.pdf). Significant correlations between abundance and percent of coble/cobble composite substrates were recorded for Cancer irroratus at Jamesville $(r=0.14, \mathrm{p}=0.007)$ and Kempt Head ( $\mathrm{r}=0.19, \mathrm{p}<0.001)$ and for Dyspanopeus
W/i, $\mathrm{si}$
$\mathrm{m}$
$\mathrm{sm}$
$\mathrm{s}$
$\mathrm{sp}$
$\mathrm{p}$
$\mathrm{pb}$
$\mathrm{c}$
$\mathrm{csi}$
$\mathrm{cs}$
$\mathrm{cp}$
$\mathrm{cps}$
$\mathrm{cpb}$ sayi at Benacadie $(\mathrm{r}=0.21, \mathrm{p}<0.001)$, Ross Ferry $(\mathrm{r}=0.28, \mathrm{p}<0.01)$ and Kempt Head $(\mathrm{r}=$ $0.22, \mathrm{p}<0.001)$. A positive relationship existed between the abundance of $C$. maenas and that of D. sayi (Table S9, available at http://www.int-res.com/articles/suppl/b008 p001_app.pdf) at Benacadie (2005: $\mathrm{r}=0.27, \mathrm{p}<$ 0.001; 2006: $r=0.35, p<0.001)$, Ross Ferry (2006: $r=0.26, p<0.001$ ) and Kempt Head (2006: $\mathrm{r}=0.24, \mathrm{p}=0.006)$. The abundance of $C$. irroratus was not correlated with either that of C. maenas or D. sayi.

\section{DISCUSSION}

\section{Spatio-temporal patterns in abundance}

In our study, Carcinus maenas, Cancer irroratus and Dyspanopeus sayi overlapped consistently at all 4 sites at $0.5 \mathrm{~m}$, and the abundance of each species was dependent on depth regardless of season. Species overlap was variable in deeper waters, but all species were concentrated in the shallows $(\leq 1.5 \mathrm{~m})$ in all seasons in 2005 and in August of both years. The overlap among species in shallow waters suggests a great potential for biotic interactions over common prey and/or habitat usage. These patterns were also present for juveniles of all species, which were almost exclusively found at $0.5 \mathrm{~m}$ depth. There was no clear evidence of a seasonal migration to shallow or deeper waters as water temperatures changed.

Because of the wide ranges in temperature and salinity observed in the BDOL, all 3 decapods are exposed to the extremes of their environmental tolerances that can influence population survival and, consequently, species interactions. Annual fluctuations in temperature are known to influence the survival and recruitment of some crustacean species. For example, the abundance of Carcinus maenas varies significantly with winter temperature (Welch 1968, Klein Breteler 1976, Beukema 1991), and cold winters can reduce survival, delay settlement and retard larval development. In the BDOL, water temperatures $<0^{\circ} \mathrm{C}$ are common in winter and lasted for 2 mo in 2005, whereas, in 2006, the winter was warmer and ice coverage was minimal. Overall, the abundance of $C$. maenas was much lower in 2005 than in 2006. In 2006, warmer water temperatures likely resulted in an increased abundance of C. maenas through a combination of greater overwintering survival of mature females and 2005 recruits (e.g. Benacadie and Kempt Head) and a strong recruit- 


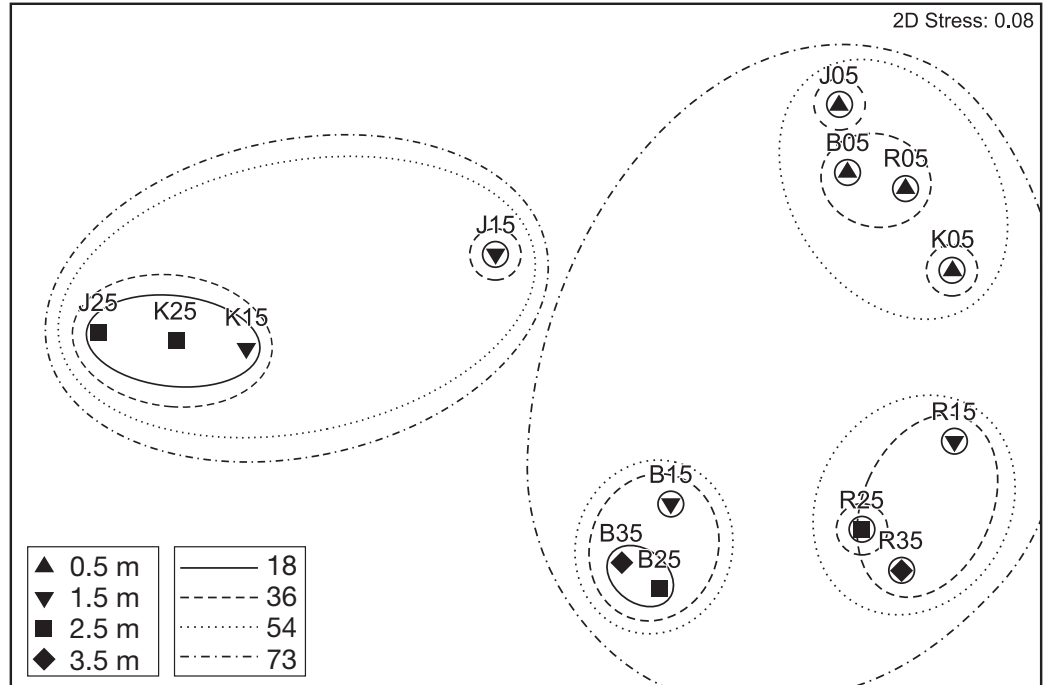

Fig. 8. Multidimensional scaling analysis of percent substrate composition sampled at each depth $(0.5,1.5,2.5,3.5 \mathrm{~m})$ at Jamesville $(\mathrm{J})$, Benacadie (B), Ross Ferry (R) and Kempt Head (K). Distance indicates Euclidean distance with smaller numbers indicating greater similarity among site/depth combinations

ment pulse in October 2006 (e.g. Ross Ferry and Kempt Head). In comparison, the abundances of Cancer irroratus and Dyspanopeus sayi were less variable between 2005 and 2006, suggesting that cold winter temperatures and ice coverage do not have the same effect on the over-wintering survival of these 2 species as for C. maenas. However, the abundance of D. sayi was elevated in October 2006 at Ross Ferry and Kempt Head due to a recruitment pulse. A mature female $D$. sayi ( $8 \mathrm{~mm} \mathrm{CW}$ ) can moult 4 to 5 times during the first reproductive season (when water temperatures are $\sim 18^{\circ} \mathrm{C}$ ), spawning in between each of these moults (Swartz 1978). The largest young-of-the-year can reach a carapace width of from 8 to $12 \mathrm{~mm}$ (Swartz 1972). Thus, the longer duration of warmer temperatures recorded in spring/summer 2006 likely enabled mature female $D$. sayi to spawn more frequently, resulting in both high recruitment and survival and, consequently, peaked abundances in the fall.

The lack of a recruitment pulse for Cancer irroratus suggests that either juvenile rock crab do not preferentially settle in the areas or depths sampled in our survey, or that juvenile survival is low overall in the $\mathrm{BDOL}$, or that recruitment is irregular and there was no large pulse during our study period. It is possible that the low salinities found in the BDOL inhibit larval survival and recruitment to the benthos, preventing a pulse of high recruitment. The reproductive strategy of C. irroratus in the BDOL and surrounding areas is not well known. We never found berried females of this species, and very few large $C$. irroratus of either sex were recorded. The abundance of $C$. irroratus was extremely low in Benacadie, an area where low salinities have been recorded repeatedly.

\section{Relationship between species abundance and substrate type}

Substrate composition had a significant influence on the abundance of each of the 3 species at a particular depth or site in the BDOL. Both juvenile and adult crabs $(<30 \mathrm{~mm} \mathrm{CW})$ of all species were consistently found at $\leq 1.5 \mathrm{~m}$ depth, where the percent of cobble/cobble composite material in the substrate was greatest. The cobble and cobble composite sediments in the shallows are more complex than the substrate at the deeper depths and contain more interstitial spaces that can provide refuge for small and juvenile crabs. Bivalve prey including oysters and mussels are also more abundant in the shallow, complex substrates compared to in soft sediments (clam populations were low in our study sites). Sand contributed the greatest to the substrate composition observed at 1.5 and $2.5 \mathrm{~m}$ depth, where crabs were rarely observed or their abundance was low.

The low abundance of Dyspanopeus sayi in Jamesville may be the result of a high proportion of sand or sand composites across all depths. D. sayi avoid sandy habitats because the fine-grained particles can reduce their respiratory efficiency by clogging their gills (Day \& Lawton 1988). The tolerance of Carcinus maenas and Cancer irroratus to sandy substrates is currently unknown, but morphological adaptations that prevent gills from clogging can be species specific within a genus (e.g. Hemigrapsus oregonensis vs. H. nudus; Low 1970).

\section{Species associations}

There was a strong correlation between the abundances of Carcinus maenas and Dyspanopeus sayi at Benacadie in both years and at Ross Ferry and Kempt Head in 2006. This overlap and association may relate to the habitat conditions at micro-scales $\left(<1 \mathrm{~m}^{2}\right)$, and suggest that environmental requirements are similar between the 2 species. More importantly, there were no negative relationships among any of the species (an association, overlap, or active avoidance). However, most sampled crabs were juvenile or early adults. Large adult cancrid crabs are known to exhibit aggres- 
sive behaviour both inter- and intra-specifically, resulting in an active avoidance of one another at smaller sampling scales (e.g. 0 to $10 \mathrm{~m}$ ). The lack of larger Cancer irroratus in our study may be due to this behaviour, which may result in among-individual spacing that was greater than the quadrat size we used.

\section{Conclusions and implications}

Vulnerability to abiotic conditions is considered to be the major factor determining the establishment of NIS in non-native ecosystems, by slowing the invasion process or restricting establishment in certain areas (D'Antonio et al. 2001); however, this conclusion is mainly based on the climate requirements of NIS across large biogeographical scales (Levine 2008). Less is known about how micro-variability (10s m to $10 \mathrm{~s} \mathrm{~km}$ ) in abiotic conditions can influence population abundance and distribution within a specific system. In the BDOL, the vertical distributions of all 3 species (juveniles and adults) overlap temporally, indicating a strong potential for interspecific competition or predation. Inter-annual differences in the abundance of Carcinus maenas appear to be influenced by temperature, but the abundances of Cancer irroratus and Dyspanopeus sayi do not seem to be affected similarly. This vulnerability of $C$. maenas to cold winter temperatures likely modifies the potential biological interactions with native species in areas of spatial overlap. However, C. maenas have also colonized habitats outside the environmental tolerance of the indigenous crabs, which is advantageous for their establishment. For example, at Benacadie, where C. maenas were very abundant, $C$. irroratus were rarely observed and previous salinity measurements fall well below the preferred range of this species. Thus, while C. maenas are found to overlap with indigenous populations, they also have the ability to avoid potential biotic controls (e.g. competition, predation) by moving into areas less tolerable to the indigenous species. The quantification of spatio-temporal patterns in abundance and distribution of these species in the BDOL aids in the identification of locations of species overlap, where biological interactions between NIS and indigenous species are more likely to occur, and helps to determine which environmental factors may modify such interactions over both short- (seasonal) and long-term (annual) periods.

Acknowledgements. We thank M. Bravo for being an invaluable field assistant: A. J. Bernard, T. Johnson, D. Knip, J. Lindley, B. Marshall, A. Roy and M. Saunders assisted in the surveys. Three anonymous reviewers and Dr. M. J. Tremblay provided extensive comments on earlier versions of the man- uscript. This research was supported by Unama'ki - Fisheries and Oceans Canada and NSERC postgraduate scholarships to E.B., an Unama'ki - Fisheries and Oceans Canada research grant to E.B. and A.M. and NSERC Discovery and DFO Science Subvention Grants to A.M.

\section{LITERATURE CITED}

Audet D, Davis DS, Miron G, Moriyasu M, Benhalima K, Campbell R (2003) Geographical expansion of a nonindigenous crab, Carcinus maenas (L.), along the Nova Scotian shore into the southeastern Gulf of St. Lawrence, Canada. J Shellfish Res 22:255-262

Beal BF (1998) Commercial impacts and management efforts in controlling green crab populations in northern New England. Green crab: potential impacts in the Pacific Northwest, Oregon and Washington Sea Grant workshop, February 9 - 10, Vancouver WA (abstract only)

Behrens Yamada S (2001) Global invader: the European green crab. NOAA Oregon Sea Grant, Oregon State University, Cornvallis, OR

> Beukema JJ (1991) The abundance of shore crabs Carcinus maenas (L.) on a tidal flat in the Wadden Sea after cold and mild winters. J Exp Mar Biol Ecol 153:97-113

Breen E, Metaxas A (2009) Effects of juvenile non-indigenous Carcinus maenas on the growth and condition of juvenile Cancer irroratus. J Exp Mar Biol Ecol 377:12-19

Broekhuysen GJ Jr (1936) On development, growth and distribution of Carcinides maenas (L.). Arch Néerl Zool 2: 257-339

Cameron B, Metaxas A (2005) Invasive green crab, Carcinus maenas, on the Atlantic coast and in the Bras d'Or Lakes of Nova Scotia, Canada: larval supply and recruitment. J Mar Biol Assoc UK 85:847-855

> Carlton JT (1989) Man's role in changing the face of the ocean: biological invasions and implications for conservation of near-shore environments. Conserv Biol 3: 265-273

Carlton JT, Geller JB (1993) Ecological roulette: the global transport of nonindigenous marine organisms. Science 261:78-82

Clarke JM, Warwick RM (2001) Change in marine communities: an approach to statistical analysis and interpretation. PRIMER-E, Plymouth

Crothers JH (1968) The biology of the shore crab Carcinus maenas: the life of the adult crab. Field Stud 2:597-614

D'Antonio C, Levine J, Thomsen M (2001) Ecosystem resistance to invasion and the role of propagule supply: a California perspective. J Mediterr Ecol 2:233-245

Day EA, Lawton P (1988) Mud crab (Crustacea: Brachyura: Xanthidae) substrate preference and activity. J Shellfish Res 7:421-426

deRivera CE, Ruiz GM, Hines AH, Jivoff P (2005) Biotic resistance to invasion: native predator limits abundance and distribution of an introduced crab. Ecology 86: $3364-3376$

Drummond-Davis NC, Mann KH, Pottle RA (1982) Some estimates of population density and feeding habits of the rock crab, Cancer irroratus, in a kelp bed in Nova Scotia. Can J Fish Aquat Sci 39:636-639

Elner RW, Lavoie RE (1983) Predation on American oysters (Crassostrea virginica [Gmelin]) by American lobsters (Homarus americanus Milne-Edwards), rock crabs (Cancer irroratus Say), and mud crabs (Neopanope sayi [Smith]). J Shellfish Res 3:129-134

Ford SD (1996) Range extension by the oyster parasite Perkin- 
sus marinus into northeastern United States: Response to climate change? J Shellfish Res 15:45-56

Grosholz ED, Ruiz GM (1995) Spread and potential impact of the recently introduced European green crab, Carcinus maenas, in central California. Mar Biol 122:239-247

Haefner PA Jr (1976) Distribution, reproduction and moulting of the rock crab, Cancer irroratus Say, 1817, in the midAtlantic Bight. J Nat Hist 10:377-397

Hunt CE, Behrens Yamada S (2003) Biotic resistance experienced by an invasive crustacean in a temperate estuary. Biol Invasions 5:33-43

Jensen GC, Armstrong DA (1991) Intertidal zonation among congeners: factors regulating distribution of porcelain crabs Petrolisthes spp. (Anomura: Porcellanidae). Mar Ecol Prog Ser 73:47-60

Klein Breteler WCM (1976) Settlement, growth and production of the shore crab, Carcinus maenas, on tidal flats in the Dutch Wadden Sea. Neth J Sea Res 10:354-376

Leppäkoski E, Olenin S (2000) Non-native species and rates of spread: lessons from the brackish Baltic Sea. Biol Invasions 2:151-163

Levine JM (2008) Biological invasions. Curr Biol 18:57-60

Lonsdale WM (1999) Global patterns of plant invasions and the concept of invisibility. Ecology 80:1522-1536

Low C (1970) Factors affecting the distribution and abundance of two species of beach crabs Hemigrapsus oregonensis and $H$. nudus. MS dissertation, University of British Columbia, Vancouver, BC

Marsh GA (1973) The Zostera epifaunal community in the York River, Virginia. Chesapeake Sci 14:87-97

MacKenzie CL Jr (1977) Predation on hard clam (Mercenaria mercenaria) populations. Trans Am Fish Soc 106: 530-537

Naylor E (1962) Seasonal changes in a population of Carcinus maenas (L.) in the littoral zone. J Anim Ecol 31:601-609

Paavola M, Olenin S, Leppäkoski E (2005) Are invasive species most successful in habitats of low native species richness across European brackish water seas? Estuar Coast Shelf Sci 64:738-750

Petrie B, Bugden G (2002) The physical oceanography of the Bras d'Or Lakes. Proc NS Inst Sci 42:9-36

Editorial responsibility: Angus Atkinson, Cambridge, UK
Petrie B, Raymond J (2002) The oceanography of the Bras d'Or Lakes: general introduction. Proc NS Inst Sci 42:1-8

Rathbun MJ (1930) The cancroid crabs of America of the families Euryalidae, Portunidae, Atelecyclidae, Cancridae and Xanthidae. Bull US Natl Mus 67:183-203

Ruiz GM, Fofonoff P, Hines AH (1999) Non-indigenous species as stressors in estuarine and marine communities: assessing invasion impacts and interactions. Limnol Oceanogr 44:950-972

Sastry AN, McCarthy JF (1973) Diversity in metabolic adaptation of pelagic larval stages of two sympatric species of brachyuran crabs. Neth J Sea Res 7:434-446

Squires HJ (1970) Lobster (Homarus americanus) fishery and ecology in Port au Port Bay, Newfoundland, 1960-65. Proc Natl Shellfish Ass 60:22-39

Strain PM, Yeats PA (2002) The chemical oceanography of the Bras d'Or Lakes. Proc NS Inst Sci 42:41-68

Strieb MD, Bricelj VM, Bauer SI (1995) Population biology of the mud crab, Dyspanopeus sayi, an important predator of juvenile bay scallops in Long Island (USA) eelgrass beds. J Shellfish Res 14:347-357

Swartz RC (1972) Postlarval growth and reproductive biology of the xanthid crab, Neopanope texana sayi. PhD dissertation, College of William and Mary, Williamsburg, VA

Swartz RC (1978) Reproductive and molt cycles in the xanthid crab, Neopanope sayi (Smith, 1869). Crustaceana 34: $15-32$

Tremblay MJ (2002) Large epibenthic invertebrates in the Bras d'Or Lakes. Proc NS Inst Sci 42:101-126

Underwood AJ (1981) Techniques of analysis of variance in experimental marine biology and ecology. Annu Rev Oceanogr Mar Biol 19:513-605

Welch WR (1968) Changes in abundance of the green crab, Carcinus maenas (L.), in relation to recent temperature changes. Fish Bull (Wash D C) 67:337-345

Williams AB (1984) Shrimps, lobsters, and crabs of the Atlantic coast of the eastern United States, Maine to Florida. Smithsonian Institution Press, Washington, DC

- Wolff WJ (1998) Exotic invaders of the meso-oligohaline zone of estuaries in the Netherlands: Why are there so many? Helgol Mar Res 52:393-400

Submitted: July 9, 2008; Accepted: September 16, 2009 Proofs received from author(s): November 19, 2009 